THE EUROPEAN JOURNAL OF LIFE WRITING VOLUME X (2021) MO68-MO91

\title{
MO Diaries and Their Editors ${ }^{1}$
}

\author{
Patricia and Robert Malcolmson
}

\begin{abstract}
In August 1939, MO asked its volunteer Observers 'to begin keeping day-to-day personal diaries of everything that happened to them, the conversations they heard and took part in, their general routine of life, and the impact of the war on it'. More than 450 individual diarists wrote for $\mathrm{MO}$ during the war. Each diarist had to work out their own way of 'observing', and to create a comfortable authorial voice expressing their very varied personal concerns and experiences. Common themes included: outbreak of war; evacuation of children; the blackout; the call-up for compulsory service; and what was thought of as 'morale'. The diaries show keen minds struggling hard to make sense of the unfolding war news, striving to understand the deeper currents of history and future possibilities in international affairs. Other themes concerned the home front: the wartime difficulties around food and transport; attitudes to class, and the arrival of American troops; and the hopes and fears for post-war reconstruction. This article reflects on its authors' considerable experience of selecting and preparing $\mathrm{MO}$ diaries for publication. Editors play a prominent role in the presentation of modern life history. This involves technical and/or literary judgments (about the length and quality of texts, the provision of supplementary material), in relation to the requirements of particular publishing formats (commercial or scholarly). It also involves ethical questions. MO diaries, once submitted, could not be revised; their authors were promised anonymity. Hence
\end{abstract}

This article is licensed under the Creative Commons Attribution-NonCommercial-NoDerivatives 4.0 International License (CC BY-NC-ND 4.0) 
publication often requires the consent of the diarists (though few are still alive) or their heirs; and measures are sometimes required to protect the identities of people mentioned.

Keywords: diaries, Mass Observation, World War Two, editing, research ethics

In later August 1939, according to a leading figure in Mass Observation, Bob Willcock, MO decided to ask 'as many' of its volunteer Observers 'as could spare the time and energy to begin keeping day-to-day personal diaries of everything that happened to them, the conversations they heard and took part in, their general routine of life, and the impact of the war on it' (Willcock, 450). (The initial request was actually made shortly before the declaration of war on 3 September.) Diaries were conceived of as sorts of 'subjective cameras', and as legitimate forms of recording, of both self and society (Madge and Harrisson, 66). Around 135 people sent in diaries for some or all of the tense days of late August/early September 1939, and many of them entitled their submissions 'Crisis Diary', later changed to 'War Diary'. Thereafter the numbers of diaries submitted (usually fortnightly or monthly) were almost always lower, though still impressive. In October 1939 slightly over 100 diarists wrote for MO.

While more than 450 individual diarists wrote for MO during the war, after 1939 the number writing at any one time never exceeded 100. The numbers fluctuated during 1940: just over 90 in February, around 65 in May, 85 in June, almost 100 in August, and about 75 at the end of the year. During the second half of the war the monthly total of diarists was normally in the 50 s or $60 \mathrm{~s}$, and the ratio of male to female diarists was usually close to 50/50 until mid-1944, when women came to predominate. ${ }^{2}$ As for quality, a higher proportion of the men's diaries are brief and mechanistic. From the beginning, MO's best diarists tended to be women. Many more of their diaries than those of men have now been edited and published, and some convey a rich sense of a life history, as it unfolded uncertainly through daily routines. ${ }^{3}$

\section{The Diaries and their Contents}

MO's wartime diarists as a group wrote about almost everything under the sun. This, of course, is to be expected, for they were not responding to specific questions, their personal concerns and experiences varied tremendously, and they were encouraged to 
take whatever approach to diary-writing suited them. A middle-aged housewife (no. 5433) who had evacuated from Kent to St. Mary Bourne, Hampshire, some five miles from Andover, portrayed in detail her everyday life, and the lives of her neighbours, in and near the village during 1942; a parson in Lincolnshire (no. 5110) wrote regularly of his pastoral duties and the secular lives of his parishioners; the Langdale Chase Hotel in Windermere, its staff and guests, were featured in the diary of a young woman working there (no. 5290) for several weeks in the summer of 1941; and a diarist in Glasgow (no. 5390) said a lot about the Soroptomist Club meetings she attended. Some writers were very matter-of-fact, others more self-disclosing (at least from time to time). Some focused largely on public events, or at least reports of these events, especially war news, while others had a lot to say about family, friends, neighbours, fellow-workers, and the like. Many wrote entries that were fairly brief and unelaborated, while a few wrote very fully and at length about their day's thoughts and activities - a handful at great length.

Each diarist, particularly those who wrote for more than a few months, had to work out his or her own way of 'observing', and to create a comfortable authorial voice. Many diaries mainly itemize the day's activities or respond to the news of the day (most of it censored); several are ruminative and opinionated, and sometimes unpredictable. A few diaries are full of complaints. Some report lots of conversations, some overheard, some in which the diarist actively participated. Many diaries are sketchy and thin. Others (less numerous) are richly elaborated, at least at times, and attentive to all sorts of minutiae these, of course, are the diaries, composed by people with an observant eye, that are most likely to attract the attention of editors. Most diaries are fairly impersonal in tone and reveal little of the writer's emotional life or intimate relations. A few diaries, though, are sometimes forthright and self-disclosing, and shed light on that person's pain and unhappiness that may well have been revealed nowhere else. What follows is an account of some of the main themes and topics, insights and revelations, which are found in these diaries.

First, MO diaries reveal a lot about people's reactions to the startling, often unprecedented challenges of existence in wartime Britain. Diaries testify to people's thoughts and feelings about the outbreak of war; the widespread evacuation of children and some of their mothers from large cities; the nightly blackout - and its sometimes assiduous enforcement; the sight of barrage balloons, trenches in parks, and other signs of military preparation on the home front; the calling-up of men for compulsory service; and what was thought of as 'morale'. When the war became really hot for Britons, from 
May 1940, diaries shed light on individuals' reactions to Churchill's leadership, the fall of France, various news bulletins, the extraordinary enlargement of state power, and the consequences for civilians of German air raids - actual, feared, and rumoured - especially after the start of the Blitz on 7 September 1940. As diaries reveal, citizens and families coped and struggled with these stresses in many different ways.

There is a great deal of evidence in MO's diaries concerning the news of the day. Much of this is easy to locate, for the relevant dates are known exactly: the attack on Pearl Harbor and the entry of the Americans into the war; the fall of Singapore in February 1942, and a few months later Tobruk; the increasing air raids on Germany - the big raid on Cologne was still the 'talk of the town', according to a young soldier on 2 June 1942 who was based in Scotland (no. 5177), and opinion was 'practically unanimous that we should carry out raids like this as often as possible'; the Allied victories in North Africa in November 1942; Britain's dam-busting raids in May 1943; D-Day, and the consequent victories and setbacks in Western Europe; the 22 July 1944 attempt on Hitler's life; and of course the final defeat of Germany in April and May 1945. The reactions to the shock arrival of the atomic bomb in August 1945 are particularly striking, a few of them remarkably prescient. Many diarists responded immediately to these various big items of news. Some war-topics persisted and were often remarked on: the news of Russian resistance to Germany after June 1941 was avidly followed for months; the prolonged debates over the wisdom and timing of a Second Front received a lot of attention, as did the news of naval battles and strategic developments in the Far East; and of course there was almost constant concern for the Allied advances (and a few setbacks) during the months between June 1944 and April 1945, by which time only the exact day of Germany's surrender was in doubt.

While this testimony reveals a lot about people's mood swings between pessimism and optimism, its value is limited in part by the fact that all the news was censored and massaged, in part by the fact that most people were not in a position to hold informed views on these matters (in contrast to matters with which they had first-hand experience). Still, it can be of interest to watch keen minds struggling hard to make sense of the unfolding war - Leonard Adamson (no. 5004) made these attempts almost daily ${ }^{4}$ and to observe thoughtful people striving to probe beneath the surface and understand the deeper currents of history and future possibilities in international affairs. A few writers, for example, even as they welcomed Russian victories, correctly anticipated future tensions between the Soviet Union and its Western Allies. There is much speculation in 
diaries as to the 'real reasons' for puzzling occurrences and what were seen as surprising political events, such as the volte-face in November 1942 by the Vichy regime's Admiral Darlan and his assassination a few weeks later.

Some of the initiatives that attracted comment were on the home front. These included the Beveridge Report of December 1942, which laid the foundations for a welfare state and was much discussed by diarists for months thereafter; the release from prison of the Fascist leader Oswald Mosely in November 1943; the V1 attacks on the south-east in the summer of 1944 and consequent temporary evacuation of at least a million people; the partial ending of the blackout in September 1944; and of course the words and actions of the nation's major political actors. Churchill's broadcasts usually attracted widespread attention, often winning overwhelming endorsement (less so at times in 1942 and thereafter), including from diarists with little use for the Conservative Party. There were a few speeches that were controversial, such as his Mansion House address of 9 November 1944, which some thought he gave while drunk. Diarists who listened a lot to the wireless routinely rendered judgments on what the BBC was programming, and regular offerings such as the Brains Trust and Postscript - the writer J.B. Priestley was the most acclaimed voice on the latter - are frequently mentioned.

If one had to cite a topic that almost all diarists mention in some form or other, it would be food (though for some women the blackout was a close contender). As the assistant in a Dewsbury grocery shop put it on 3 September 1941 (no. 5331), 'Curious how "het up" everyone gets over food... Food really hits the tender spot.' From 1940 food could no longer be taken for granted, even by those accustomed to a well-stocked pantry and servants to do the work (from later 1941 these domestic servants were vanishing). Food is talked about routinely in diaries - its quality and quantity, its availability or scarcity, how it was marketed, how it was prepared and consumed, how it was (allegedly) wasted, how it was occasionally enjoyed. 'Met a friend today', wrote a London secretary (no. 5429) on 11 February 1943, 'who told me she bought a large tin of Bartlett pears the very first moment they were released on Monday morning last, and shared it out amongst her family at tea-time. When the table was set, she said “Now we mustn't talk. Just concentrate on the pears and get the utmost out of them." So they ate in silence, as though partaking of a sacrament.'

The war had an impact on everyone's eating. One can read in diaries of the food served at canteens and to members of the Forces and in British Restaurants (a wartime novelty); of the fluctuating supplies in grocery and other shops; and of pubs running dry. 'Several 
pubs closed in Mansfield today,' according to a man who worked in a boot factory there (no. 5039.2) on 6 August 1941. 'No Beer. At least one of the few which were open had a long queue.' Diarists wrote about the prices of produce in local markets; gathering berries and other wild edibles in late summer and early autumn; dried eggs and Spam; collecting kitchen waste for pigs and keeping hens in the back garden; and of course the changing complexities of rationing, which left many people befuddled and not always aware as to what was legal and illegal, or, if aware, not necessarily prepared to stick to the letter of the law. Readers of Nella Last know that provisioning is one of the staple topics of her voluminous diaries - and even more so, in fact, in the originals than in the selections that have been published. ${ }^{5}$

There are other matters that commonly arise in diaries, usually those that were part of many people's everyday lives. Transportation was a recurrent concern: the queues for and congestion on local buses, the vagaries of train travel. Class-consciousness was sometimes starkly expressed, one outcome, perhaps, of wealthier people coming in contact more often with those of plebeian backgrounds, especially during the second half of the war when some of the buffers of class (servants, cars, luxury goods) were gone, and virtually all labourers were employed and often earning (to some, alarmingly) good wages.

Many diarists wrote of illnesses (such as skin disorders) that they attributed to wartime privations, perhaps an unbalanced diet, lack of sleep, or over-work. Some reported intermittently feeling blue, and many mentioned persistent fatigue. Life frequently felt tedious. 'Fed up with the ceaseless scramble of living,' sighed a middle-aged London secretary (no. 5429) on 29 January 1943, 'no let-up, anywhere, and don't get enough sleep. Leave off work to carry bricks, so to speak.' While the routines of life naturally varied a lot from person to person, one often reads in diaries about the increased burdens of housekeeping, the hours devoted to voluntary work, and such extra wartime duties as fire-watching. ${ }^{6}$

A few diaries were written from an unusual and distinctive perspective. Two of these were rooted in illness, one by a patient, the other by a student nurse. The patient (no. 5303) was a 22-year-old shorthand typist who had enlisted in the ATS (the women's auxiliary of the Army) but been struck down by polio. During most of 1944 she was constantly in hospitals, where she wrote of the medical treatments of the day, how she coped with her disease, and the people she met, from 'poor ancients' to handsome young men reduced to stretchers and wheelchairs. In Blackburn, Lancashire, a student nurse 
(no. 5344) kept a detailed diary of her everyday life in hospital. She recorded her long shifts; attempts to study for her exams; the diversity of her work, from the operating theatre to the out-patient ward and the male surgical ward, with its occasional boisterousness; and the various entertainments provided for patients - all the while trying to control her own anxiety (her boyfriend was a POW). She witnessed the preparations to receive D-Day casualties; she told of her work in helping to care for them - the nurses were much interested in the tales their patients told, some horrifying - and the early use of penicillin, 'which entails a lots of extra work for the nursing staff' (29 June 1944). She also wrote of the extraordinary strains in the hospital when German POWs arrived for treatment (some were SS), the resultant fury of some of the other patients and staff, and the outright refusal of a physician who had lost most of her family on the Eastern Front even to enter the ward in which they were segregated.

Some topics that were rarely mentioned by diarists during the first half of the war make frequent appearances during the second half. One of these is Americans, whose presence in Britain became a prominent issue during (in particular) the couple of years before mid-1944. An early impression was recorded on 4 July 1942 in the diary of a factory worker in Mansfield, Nottinghamshire (no. 5039.2). 'American troops stationed in this town (Medical Corps). To my mind, they are very slovenly. People don't seem to think much of them.' One is struck by how unwelcome this Allied presence was in many localities, and the extent, even rabidity, of anti-American sentiment. Many disliked the free-spending ways of Americans (especially when shoved in the faces of hard-up, constrained Britons); they deplored American boasting and, as they saw it, supercilious strutting, and might even gloat when US troops took a beating abroad.

Then there was what was seen as the sexual assertiveness of Americans in uniform on 15 September 1944 a diarist in her late twenties (no. 5239) and a female friend were walking near Winchester and 'We were shadowed by two Americans on the way home. They are a nuisance.' (She had reported one previous similar incident.) Some writers lamented the effect Americans were having on impressionable British girls; others condemned the permissiveness of the girls. This negative opinion was not always based on actual face-to-face relations with individual Americans (as in the incident above). Rather, it was sometimes a product of rumour, reputation, and hearsay, or fleeting impressions. Still, whatever its sources, these stories clearly grabbed people's attention, and shaped their thinking. MO diaries are in fact a rich repository of anti-American sentiment. (Pro-American views were expressed, but much less frequently.) 
Another significant change as 1942 was ending and 1943 beginning was that worry about the possibility of invasion largely disappeared, and talk of what would or should happen in Britain after the war became widely prominent, occasionally to the point that it pushed aside remarks about the continuing war. Some diarists looked pessimistically into the future. On 13 April 1944 a Londoner (she lived near Morden [no. 5444]) talked with a woman in a queue and they 'agreed that things will be tough for a long time'. Shortly before that, when the miners were taking industrial action and coal supplies were threatened, another London diarist (no. 5349) thought on 13 March 1944 that it was 'no wonder the country at large is worried about after the war. These strikes are the shape of things to come, [and] to most people are more of a portent than the pious platitudes of the Education Bill, new medical service and other pronouncements.'

Other diarists were more optimistic. Certainly everyone wanted the war to end as soon as possible, and speculation was rife as to when that would be. Virtually all diarists expected a different world from that of the late 1930s - and some hoped for a better world than before, including people who were by no means radical or especially pro-working class. Reform was in the air, and diarists in 1943 and 1944 testified to these changes in outlook. This looking ahead was often accompanied by a marked war-weariness; during much of the war observers were inclined to underestimate how much longer hostilities would last, though their estimates were all over the map and depended heavily on the mood of the moment.

'This war will not have been worth fighting unless we are going to make a better world afterwards,' wrote a 27-year-old woman (no. 5239) on 2 December 1942, the day the Beveridge Report was published, 'and we've got to begin planning for that now.' This opinion, the exact opposite of Churchill's, is found in many other diaries, though they also report the doubts of fiscal conservatives. Diaries from December 1942 and many months of 1943 are full of references to postwar social security, and whether and how it might be achieved. We offer just one example of conversation on this subject, partly because the context was unexpected and shows how these issues were then at the forefront of people's minds. Annie Holness, a London civil servant evacuated to Morecambe (no. 5338) and a great walker, was looking to stop for tea in Kirkby Lonsdale on 22 May 1943 and found a cottage in the square with a 'Refreshments' sign. There she was served by an elderly couple, and they got to chatting. 
He had done lots of jobs, including that of relieving officer [for the poor]. That set him talking about the Beveridge Report and other proposed social reforms. He said that although we do of course need social reforms, we ought to wait to see what we can afford. ... He believes in relieving real need, but thinks people ought to be self-reliant. He thinks (or knows from his experience as relieving officer) that there are plenty of malingerers, out to get all they can. He's also a great gardener. It was a most interesting tea.

Some diaries include at least occasional reports of strong personal feelings - fear, perhaps, or self-doubts, or regrets, or frustration, or exhilaration, or prejudice (notably antiSemitism). A diary might momentarily become a sort of confidante - more so for women than men. It could be a place to brood, and to put one's usually unarticulated feelings, perhaps feelings that almost no other person was privy to. A well-educated 28-year-old (no. 5239) whose husband was posted to India was trying to cope in 1943-44 with her somewhat lonely life in Hampshire, where she was employed in aeronautical research (she was a mathematician). 'I want some friends of my own age,' she wrote on 29 October 1943, 'and they are all far away.' She wanted 'to break the monotony of life' (30 October 1943). A couple of months later (4 January 1944):

I had letters telling me of two more of my friends who are expecting their first babies. It brought out the blankness of my present existence all over again, just when I was beginning to become reconciled to a certain extent. All my friends seem to have either babies, or their husbands in England, or both, and I have neither.

A diary could be a place to deposit anxieties. On 21 June 1942 a mother in Bedford (no. 5451) was worrying about her son in the Forces - even before he saw combat. The young man, in his late teens, wanted to get married before being sent abroad.

So many of his young friends are married or about to marry and he argues that as he has no certain future he is entitled to present happiness. ...It is very hard to instill caution. The most we have been able to do is to make him see that regard for his welfare, mistaken regard as he thinks, makes us refuse consent. But we cannot be sure that we have the right to deny him temporary happiness, even if caution prompts us to remember the years after the last war. Our son is self-reliant, and adaptable; the girl 
he wishes to marry is just the opposite. Is it fair to allow him to throw away his youth and take on, so young, the responsibilities of marriage, burdened with a spoilt and delicate wife? It is very hard to refuse him and to risk the destruction of confidence between us. It is a problem for a wiser head than mine to solve.

Towards the end of the year (3 December 1942) this woman was worrying about her stressed and (perhaps) over-conscientious husband, who was employed in a munitions works and an active trade unionist. 'He is at heart the same straightforward honourable man, but in little ways there is scarcely a trace of the lighthearted boy I married.' His war work, she felt, had 'robbed me of my old companion. Whereas we once shared our lives in every particular, as union matters have absorbed him, I have found other interests and am amazed at how far we have drifted apart, while having no vestige of quarrel between us.' It may be that she revealed this 'personal matter', as she put it, to no one else.

Very occasionally a passage in a MO diary reads as if it were part of a confessional, or perhaps a disclosure to a therapist. On 27 June 1940 a single woman in her mid-twenties, a civil servant living in Croydon (no. 5383), gave vent to her accumulating resentment concerning 'the injustice of "nature" in the way of sex' - 'It began when I saw a young friend of mine with her "boy"'. This mood took her over at a time when most of her writing focused on other matters, mainly the war.

The men have far the best time, I argued within my mind; they can pick and choose their girls, and can have all the satisfactions they want without having to get married. If girls do this they are worried all the time by the risk of "consequences". So that, if I am ever to get sexual satisfaction, it will mean selling myself to one man for life, to be cooped up in a little suburban house with a dreary household routine... The problem is awful, and my resentment grows as I realise that I have little chance of solving it. Yet even as I write these words I can't help standing aside and laughing at my queer mood.

Diaries were well-suited to capturing such moods of the moment. On 11 November 1943 a 42-year-old Birmingham housewife (no. 5420) was thinking back twenty-five years to the Armistice. 'I was seventeen with long curls down my back, happy in a way because I was my Mother's right hand. I had started mixing with the older boys. I mixed but cautiously.' This recollecting then led her to a sudden major self-revelation. 'I was still 
suffering from the after effects of attempted rape at the age of fifteen. Even today my Mother is ignorant of that crisis in my life' and the traumatic impact it had had on her.

Diarists sometimes took particular interest in someone they had met, or something they had observed, and recorded the details. On 1 January 1943 a worker in a boot factory in Mansfield (no. 5039.2) wrote sensitively of the exhaustion experienced by a miner he'd met who had been conscripted for part-time duty in the National Fire Service. A woman in her early fifties in Crouch End, London, N8 (no. 5438) wrote on 3 April 1941 of a visitor that day.

My friend who is helping with evacuees in Somerset is home on leave. She spent yesterday evening and night here. I feel young and gay this morning after seeing her! We sat over the fire until after midnight and had breakfast at 9.45 after my husband and son had gone to school. I've smoked three cigarettes with her and eaten a whole lot of chocolates, with some Birley's Anti-acid Powder to avert evil consequences! Life is quite different when one has friends near enough to meet. We talked of her life very hard work and terribly lonely. She is in a Manor House and marvellously treated, but, after all, we are people in a different walk of life. She says how lonely and miserable are the London mothers in the village. They have to go out every day and push prams thro' muddy lanes.

Social barriers were sometimes spoken of, usually those of class or gender, and could provoke pointed, even moving, observations. In November 1944 a 30-year-old from Welwyn Garden City (no. 5450) found herself in Gateshead training to become a probation officer. This was a part of Britain that she not familiar with. After visiting the house of a client, she did some pondering (2 November):

The people are so poor and the depression will probably leave its mark permanently, in the dull faces of the people, waiting for the next blow to fall. I wish some of my Southern friends could come with me. I think we would have a change of government, and system, very much more quickly! The number who are not able to read or write, never having attended school because of ill health and/or poverty, is incredible, and a woman of 25-30 looks at least well over the 40 stage! 
The following day she visited some cases in nearby country districts. 'I was struck with the poverty of these folk, but their pride runs high still in many cases and I cannot help but admire them.' Three days later, after more visiting, which included Sunderland and some mining villages, she remarked that 'there seems so little hope in anyone or anything and after the war are things going to be really any better?' On 8 November she concluded that information on birth control was much needed - she had just seen a 'very poor household where the wife has asthma (and looks almost a TB case) and has had three children in three years!' (Cases of suffering are also reported in the diary of the Medical Officer of Health mentioned above, based on his exposure to West Bromwich during the second half of 1941 [no. 5067].)

MO's diarists were volunteer 'Observers', and one encounters in some of their writing passages in which social life is closely observed. An opinionated housewife in her forties (no. 5423) who lived just outside Bradford had a good reporter's eye. On 8 February 1942 she addressed the matter of yet another wartime constraint.

The soap ration seems to me scarcely enough for us people up in the Northern industrial areas, especially us who do our own washing. I should say it will be ample for households who live in the country, in town flats with fitted carpets etc., and nonindustrial districts, but in houses like those in this district, with floors and surrounds to be scrubbed every week, and paint which ought to be washed every month, I'm sure it is not enough. Take curtains alone. Lots of people in the country need only wash curtains once a year, many only twice, but here they must be washed about every six weeks. Wonder who fixed the ration. Man or woman? Where do they live? And how much washing have they ever done? Of course, my husband swears that it is a woman like [Conservative MP] Lady Astor who has advised on the subject!

Women in industrial areas had, she thought (20 March 1943), 'a hell of a life', made worse by the extra burdens of keeping house in wartime.

Here, then, is a smorgasbord of comments on the wide range of testimony and opinion, description and emotion, which is found in Mass Observation's collection of diaries. Of course, for many of these topics it would be, if not fruitless, certainly grimly laborious to go searching for evidence through the entire collection. What exists is bitty and wellhidden - needles in haystacks. Thus, in part, the importance of edited publications, 
especially ones with indexes, which permit researchers to locate readily the evidence that interests them.

\section{The Diaries and their Editors}

Why have certain diaries been selected for publication, while most have remained unpublished? One answer is that most MO diaries are too short to justify a book. Their authors wrote for only a month or two, certainly for less than a year, and sometimes their daily entries were fairly short. These probably comprise the majority of MO's diaries. There are several excellent diaries from 1940 that did not last for long and thus (we once thought) would only find a publishing outlet by means of an anthology.7 Diary-writing, for those who took it seriously, was not easy work, especially in the demanding circumstances of wartime. Writers who started strongly often gave up after a while as the pressures of wartime living (men being called up, women having to move house, other family dislocations, illness or fatigue) weighed heavily upon them. There is also quality to consider, for some writers were simply better diarists - more informative, more committed, more adept with words - than others, though on this point the judgment of editors inevitably plays a role. One person's dull diary may be of great interest to someone else.

There is one common feature of almost all the MO diaries now edited and published or in the process of being edited: their authors liked to write and were, by any reasonable standard, good or at least competent writers. Naomi Mitchison was an already established and well-known writer; Nella Last loved to write (mainly private letters before 1939) and never experienced writer's block; Denis Argent was a journalist and Leonard Adamson wanted to be a journalist; young Henry Novy was a researcher and writer for MO before starting his own diary in November 1940; ${ }^{8}$ and Reverend Arthur Hopkins, the Vicar of Skirbeck Quarter in Boston, Lincolnshire, was Cambridgeeducated, well read, and a writer of large numbers of letters. The several working women, all unmarried, whose diaries have been published - those of Doreen Bates, Kathleen Tipper, Winifred Challis, Kathleen Hey, Annie Holness, Jean Pratt, and Gladys Langford - were hard-working, disciplined, self-improving people with a talent for writing. Busy mothers with young children are not prominent among diarists. Phyllis Walther in Blandford Forum, Dorset is one exception, and she terminated her diary in mid-1942 shortly before the birth of her second child. Another is Rachel Dhonau in Sheringham, 
Norfolk, who worked for pay throughout 1941-42 and kept a lively record of her diverse activities; she could do this only because she lived with her mother, who did most of the child care and housekeeping (Rachel's husband was in the Army).

Each diary poses different challenges for its editors. First, some are too long to be published in full. This, in part, is a practical matter. Contemporary publishers have a limited interest in texts of hundreds of thousands of words, especially when they were composed by unknown authors. Perhaps someday a full or at least fuller version of Nella Last's massive diary will be published, but this will assume a multi-volume project. Then there is the issue of literary quality. Some diaries are repetitious, and it is not clear that readers benefit greatly from encountering the same opinion, the same outlook, or the same feeling, again and again. Sometimes, too, a diary that is going strong starts to slide in quality, and loses range and spark; in these cases editors may feel justified in selecting the strongest passages to print, especially when these are sufficiently numerous and substantial to comprise a full book. Thus the editors of Rachel Dhonau's diary chose to publish in full her diary only for 1941-42, and not to publish almost all that she wrote afterwards, for she was then mainly at home, expecting and in due course giving birth to her second son, and her range of experience and subject matter noticeably contracted. As for Annie Holness, a civil servant evacuated in 1940 from London to Morecambe, Lancashire, some of her days in 1941-43 were uneventful, and she often stated so explicitly. The result of our editing has been a published diary that ignores many of these (for her) unremarkable days and prints mainly the entries when she felt active and engaged and had matters of interest to record.

In a few cases it has been feasible to reproduce a MO diary in its entirety, and this is, in certain respects, obviously desirable. The reader then knows that he or she is not at the mercy of some editor, who may be omitting from the book diary-writing that this reader would like to know about. Editorial discretion can be crucial: it is noteworthy that the two selections of Nella Last's wartime writing, the first published in 1981, the second in 2012, are almost entirely different. They overlap by less than ten percent. When diaries are published in their entirety, this has sometimes been made possible by special circumstances. Phyllis Walther's diary happens to be just the right length for a short book: it covers a manageable sixteen months, and is succinctly written and rarely repetitious. Kathleen Hey's Dewsbury wartime diary, which is published in full for the four wartime years during which she wrote (1941-1945), was clearly edited by the diarist herself, and thus requires no selections by others. After some nine months of frequent and often 
detailed entries in 1941-42, she starts to write much less often, sometimes only once or twice a week, and thus ends up producing a handwritten text that is, fortuitously, roughly the size of a normal book. Much the same could be said of the diary of Olivia Cockett, whose very detailed writing at the beginning of the war and during the spring and summer of 1940, was followed by much more fragmentary efforts from September of that year. This, it seems, was largely because of both her own intense personal life (mainly involving her longstanding lover, a married man) and the trials of living in and travelling daily through blitzed London, which left her little time or energy for MO.

How editors carry out their tasks depends partly on the publisher of the diary. A key constraint is that most trade publishers are not interested in the diaries of people whose names are unknown. If Nella Last is now something of a household name, this is because the late Victoria Wood and Granada Television, in 2006, made her one, through the drama 'Housewife, 49'. A prominent actress and producer thus created a market for more of Nella's writing. ${ }^{9}$ This is a rare exception to the rule. And the rule, we have discovered, is that the most promising outlet for a relatively modern diary is a record society, normally one based in a county, which is committed to publishing primary historical sources of regional interest. Traditionally, these societies mostly published texts written before 1800, and at the beginning of this century virtually none had published any twentieth-century sources. Happily, historical interests were then expanding. By 2000 or so, the period of the Second World War was becoming sufficiently distant that 'texts' from the 1930s and 1940s, as customarily studied and valued by historians, were increasingly being regarded as suitable for editing and publication. After the first couple of such diary publications by record societies (Norfolk in 2004, London in 2006), examples were in place of what could be accomplished, and it is now rare to find resistance to proposals to publish $\mathrm{MO}$ material on the grounds that it is excessively modern.

One result of our focus on record societies as publishers of several of our editions is that we have always felt obliged to learn a lot about the localities where the diarists were settled and often the places (usually nearby) that they travelled to. Local newspapers have thus been important sources, mainly for local (rarely national) public events and incidents that were observed or remarked on by the diarist. The publisher's concerns are bound to affect what editors do. The fact that the Bedfordshire Historical Record Society was the publisher of the diary of Denis Argent, a very bookish, left-leaning conscientious objector in the Non-Combatant Corps who happened to be billeted in Bedfordshire for the better part of a year, meant that our selections were somewhat different from what 
they would have been had the publisher been, say, the Army Records Society or one particularly keen on recording the politics of early wartime dissent. Then there were those experiences on the home front that transcended locality, of which listening to the wireless was one of the most widespread. Many diarists wrote of the programmes and talks they heard (including Churchill's speeches). For several projects research in the BBC Written Archives Centre in Caversham, Berkshire has been important in constructing appropriate footnotes. Footnotes, though, are much less necessary - in fact, not wanted in editions for trade publishers. Similarly, a thorough index, which is vital for any record society or other academic volume, may not be a priority for a trade book.

The wartime diaries that survive are not, of course, exclusively found in the Mass Observation Archive. There are many others, some now published, and no doubt more that remain to be discovered and put into print. But those written for MO have two distinctive features. First, once a diary was posted to MO's headquarters, it was out of the diarist's hands. He or she no longer had control of it; MO took control. Second, MO promised its 'Observers', diarists and others, anonymity. Consequently, contributors to MO have often been referred to simply by the number that the Archive has assigned to them. They have not been named in print or they have been given pseudonyms, as Dorothy Sheridan did in her 1990 anthology, Wartime Women: An Anthology of Women's Wartime Writing for Mass Observation, Sandra Koa Wing in her Our Longest Days: A People's History of the Second World War (Profile Books, 2007), and Simon Garfield in the three volumes of diary selections that he edited (2004; 2005; 2006). These two features of MO's diaries have important implications.

The fact that diarists gave up control of the writings meant that, whatever second thoughts they might have about their diaries, it was not possible to retrieve the material. It was permanently housed elsewhere (assuming that none of it was lost, and unhappily much MO diary writing did go missing, inexplicably, either during the war or shortly thereafter). Should they have wished to alter what they had written - perhaps excise rash judgments, tone down blunt criticisms, delete bigoted or mean-spirited statements - MO diarists were unable to do so. There was no way to revise or massage their thoughts as recorded at one brief time (a key merit of diaries). What a diarist may have said in a moment of, say, anger or fear remained written (so to speak) in stone. A person's past, as a diary disclosed it, could not be rewritten. No benign touching up would be possible.

Here is a major difference between MO's diaries and both most other diaries and all memoirs. Most diaries that remain in private hands can be - and probably are, in some 
way - tampered with, if not actually trashed. Most people, looking back on what they wrote decades earlier, are unlikely to be happy with all that they had said. Rare is the raw, unedited diary that does not include confessions best forgotten - from the diarist's later, more mature point of view. Foolish, bigoted, and embarrassing remarks, and other testimonies to flaws of character, should not - their author is likely to conclude - be preserved for the delectation, even contempt, of posterity. Looking back at them, personal diaries in private hands are very likely to be 'improved', and adjusted to reflect better the diarist's later and more judicious character. Or, another strong possibility, loved ones who peruse a diary after the diarist's death are likely to be inclined to remove from its possible publication (or even presence in a public archive) any features deemed disagreeable to the family. The authenticity of MO diaries, then, has a resilience and reliability that privately-held diaries can seldom match. (Memoirs, of course, are notoriously products of the wisdom of hindsight, even when trying to be truthful and fair-minded.)

The issue of anonymity has different implications. In some cases one can demonstrate to those representing the Mass Observation Archive that a particular diarist, long deceased, almost certainly had no close surviving relatives - usually a diarist who had no children - and thus there is now no one living who could be hurt by the naming of names. This argument may be strengthened if a diarist identified people in writing mostly by their initials only (this was a common practice), and in some cases rarely if ever said much that was particularly mean or censorious. Given these facts, editors may be permitted to publish a diary under the diarist's actual name, as has now happened on several occasions (for example, the diaries of Gladys Langford, Kathleen Hey, and Annie Holness). If pseudonyms did have to be used, it is doubtful that a record society or academic press would agree to publish a MO diary, given the partial concealment of historical reality and the inability to draw upon the specificity of (say) electoral lists, probate wills, and certificates of birth, marriage, and death.

Being able to attribute a text to an actual author obviously makes it a more solid and credible source than it would otherwise be. Editors can trace and describe the diarist's family history, give details of some places and incidents that otherwise could not be given, and situate the diary fully in its local context, using electoral registers, Ordnance Survey maps, probate wills, certificates of birth, marriage, and death, and other sources of helpful specificity. In this way a diary can be presented as testimony of a particular life and times. Some of this research can be fairly specialized in nature, and we are fortunate 
to be able to draw upon the genealogical expertise of a friend in Southfields, London, Ann Stephenson, who is adept at probing sources and finding aids with which we have little familiarity.

Diaries have also been published under their authors' actual names either with the approval of the diarist him- or herself, or with the approval - and probably assistance of children and grandchildren. As Dorothy Sheridan's essay in this cluster richly details, her editing of Naomi Mitchison's diary was carried out in the early 1980s very much in cooperation with the diarist. Two MO diarists whose writings we edited were alive when we were at work: Denis Argent (b. 1917) and Kathleen Tipper (b.1919). Both diarists, after some discussion, approved of what we wished to do (with only a couple of minor exceptions), as did Denis's daughter and son-in-law. In talking with them and raising various mainly factual questions, we learned a lot about their families and wartime conditions of life that would otherwise have been entirely unknown to us. We were also able to view family photographs and use some of them in our books.

Of course, hardly any of MO's writers are still alive to consult. However, many of their children are, and their approval has often been essential. Nella Last's diary would probably not have appeared in print in 1981 without the support of her younger and only surviving son, Clifford Last. More recently, in 2006-07 the two sons of Phyllis Walther endorsed the publication of their mother's diary. So had a son of Rachel Dhonau a few years before, as well as (in 2014) the children of Joan Ridge (b. 1914), who wrote a very detailed diary from Leeds, where she and her husband were living during the first six months of the war. In editing these diaries we benefited from the active collaboration of the diarists' children, which included tours of places mentioned in the diaries, comments on our editorial practices, access to family photographs, and helpful information on family history. Of course, there may be children or grandchildren of other appealing MO diarists who would be much less cooperative, or even hostile. Some might want to cast their own spin on an ancestor's life. There is bound to be an element of luck in these matters.

All of these considerations suggest that editors can and probably do play a prominent role in the presentation of modern life history. Some of this influence involves technical and/or literary judgments, such as when and how (perhaps even if) to correct obvious errors in composition, which virtually all diarists make, at least occasionally. (A few diaries abound in slip-ups.) Often this was a function of haste in writing, and not having time to review one's writing for stigmata and infelicities. Sometimes a text, whether 
handwritten or typed, includes such manifest mistakes that even a cursory re-reading would have caught them. Typed diaries present problems of their own, for occasionally a diarist had such poor command of the machine that typos are rife, some of which confuse the intended meaning; or perhaps the ribbon or typewriter was so old that a few words did not come through on the page. Punctuation is almost always an issue that demands editorial attention, for even the best writers can be inconsistent, or whimsical, or simply wrong, and editors (in our opinion) need to intervene, if only for the sake of ensuring basic clarity. This means that editors will be 'helping' the diarist to say with precision what they think the diarist actually wanted to say, and some critics might find this objectionable. But to do nothing would often be to leave the diarist sounding muddled or clumsy - unnecessarily so - and perhaps ambiguous or even unintelligible.

What about other possible editorial interventions? Occasionally there may be a case for a stand-alone appendix that prints a detailed entry from a part of the diary that was excluded from the main text, or for presenting some unselected extracts in an epilogue. There may, too, be literary conventions to consider. Diaries were not written in chapters or as story lines. They are rooted in the classic diurnal, and commonly retain this day-byday, week-by-week, structure of routine. A published diary may simply reproduce these longstanding chronological conventions. From time to time, however, we have thought it appropriate to give a diary something of a narrative framework by introducing chapters with titles made up by us, always for diaries where much of the original writing is not being published. This was pretty much essential in presenting selections from the massive diaries of Nella Last. We also found it an approach that worked in framing the selections from both the 1941-1943 Morecambe diary of Annie Holness and the 1936-1940 London diary of Gladys Langford, which draws heavily on her MO writing for 1939. In these ventures we have been conscious of wanting to aid the diarist in, one might say, telling her life history, and, to a limited extent, in arranging it in the way that a biographer might. A story is allowed to unfold partly with the aid of some literary reshaping. A book's conclusion, in particular, is not usually rooted in any notable ending in the diarist's life; rather, it is drawn to a close in a manner designed by its editors. The need or incentive to intervene in this way is partly because most MO diarists do not consciously bring their writing to a conclusion; they just suddenly stop writing.

In conclusion, the editors of MO diaries (and perhaps other personal papers, such as letters) both acknowledge constraints and enjoy freedoms. Most of the constraints are embedded in the standard rules of editing: accuracy of transcription and presentation; 
identifications of people, places, and things when such details are likely to be helpful (normally these can be briefly presented); explication of words and expressions whose meanings are no longer widely understood, or which now benefit by being situated in a specific context. Any opinions the editors might have about the content of the diary, we think, they should keep to themselves. It's best to do the job of editing properly and leave readers to raise their own questions and come to their own conclusions and to choose what they want to make of the diarist's work. Editors have no need to proffer guidance on these interpretative matters. On the other hand, as this essay has stressed, there are many ways in which editors express preferences, make choices, exercise their imaginations, and shape a text according to their own scholarly judgments. This work has its own pleasures - one of which is the satisfaction of bringing to light fresh and interesting and previously unknown voices, and encouraging others to hear these voices. Without Mass Observation, they probably never would have been heard at all, leaving posterity the poorer for it. ${ }^{10}$

\section{Works Cited}

\section{Published MO wartime diaries}

\section{Adamson}

Malcolmson, Patricia and Robert (eds.). Warriors at Home 1940-1942: Three Surrey Diarists.

Woking: Surrey Record Society, 2012. 151-236.

Argent

Malcolmson, Patricia and Robert (eds.). A Soldier in Bedfordshire, 1941-1942: The Diary of Private Denis Argent, Royal Engineers. Woodbridge, Suffolk: Bedfordshire Historical Record Society, The Boydell Press, 2009.

\section{Bates}

Bates, Doreen. Diary of a Wartime Affair: The True Story of a Surprisingly Modern Romance. Margaret Esiri and Andrew Evans (eds.). London: Viking, 2016.

\section{Challis}

Malcolmson, Robert and Peter Searby (eds.). Wartime in West Suffolk: The Diary of Winifred Challis 1942-1943. Woodbridge, Suffolk: Suffolk Records Society, The Boydell Press, 2012. 
Cockett

Malcolmson, Robert (ed.). Love and War in London: A Woman's Diary, 1939-1942, by Olivia Cockett. Waterloo, Ontario: Wilfred Laurier University Press, 2005; second edition, Stroud: History Press, 2008.

Dhonau

Malcolmson, Robert and Peter Searby (eds.). Wartime Norfolk: The Diary of Rachel Dhonau 1941-1942. [Norwich]: Norfolk Record Society, 2004.

Hey

Malcolmson, Patricia and Robert (eds.). A Shop Assistant in Wartime: The Dewsbury Diary of Kathleen Hey, 1941-1945. Woodbridge, Suffolk: Yorkshire Archaeological and Historical Society, The Boydell Press, 2018.

Holness

Malcolmson, Patricia and Robert (eds.). A Londoner in Lancashire 1941-1943: The Diary of Annie Beatrice Holness. Liverpool: The Record Society of Lancashire and Cheshire, 2016. Hopkins

Malcolmson, Patricia and Robert (eds.). A Parson in Wartime: The Boston Diary of the Reverend Arthur Hopkins, 1942-1945. Woodbridge, Suffolk: Lincoln Record Society, The Boydell Press, 2017.

Langford

Malcolmson, Patricia and Robert (eds.) A Free-Spirited Woman: The London Diaries of Gladys Langford 1936-1940. London: London Record Society, 2014.

Last

Broad, Richard and Suzie Fleming (eds.). Nella Last's War: The Second World War Diaries of 'Housewife, 49'. 1981; London: Profile Books, 2006.

Malcolmson, Patricia and Robert (eds.). Nella Last's Peace. London: Profile Books, 2008.

Malcolmson, Patricia and Robert (eds.). Nella Last in the 1950s. London: Profile Books, 2010.

Malcolmson, Patricia and Robert (eds.). The Diaries of Nella Last: Writing in War and Peace. London: Profile Books, 2012.

Mitchison

Sheridan, Dorothy (ed.). Among You Taking Notes ...: The Wartime Diary of Naomi Mitchison, 1939-1945. London: Victor Gollancz, 1985. 
Novy

Malcolmson, Patricia and Robert (eds.). Voices from Wartime Leeds 1939-1940: Three Mass Observation Diarists. Leeds: Thoresby Society, 2017. 79-122.

Penna

Malcolmson, Patricia and Robert (eds.). A Mother in Tadworth, Surrey in 1940: The Wartime Diary of Daidie Penna. [Banstead]: Banstead History Research Group, 2019.

Pratt

Garfield, Simon (ed.). A Notable Woman: The Romantic Journals of Jean Lucey Pratt. Edinburgh: Canongate, 2015.

Ridge

Malcolmson, Patricia and Robert (eds.). Voices from Wartime Leeds 1939-1940: Three Mass Observation Diarists. Leeds: Thoresby Society, 2017. 5-75.

Tipper

Malcolmson, Patricia and Robert (eds.). A Woman in Wartime London: The Diary of Kathleen Tipper 1941-1945. London: London Record Society, 2006

Walther

Malcolmson, Patricia and Robert (eds.). Dorset In Wartime: The Diary of Phyllis Walther, 1941-1942. Dorchester: Dorset Record Society, 2009.

\section{Other Sources}

Garfield, Simon (ed.). Our Hidden Lives: The Everyday Diaries of a Forgotten Britain 19451948. London: Ebury Press, 2004.

Garfield, Simon (ed.). We Are at War: The Diaries of Four Ordinary People in Extraordinary Times. London: Ebury Press, 2005.

Garfield, Simon (ed.). Private Battles: How the War Almost Defeated Us. London: Ebury Press, 2006.

Hinton, James. The Mass Observers: A History, 1937-1949. Oxford: Oxford University Press, 2013.

Madge, Charles and Tom Harrisson (eds.). First Year's Work, 1937-38, by Mass Observation. London: Lindsay Drummond, 1938.

Willcock, H.D. 'Mass Observation.' American Journal of Sociology 48.4 (January 1943): 445456. 


\section{About the Authors}

Patricia and Robert Malcolmson are social historians whose most recent authored books are Women at the Ready: The Remarkable Story of the Women's Voluntary Services on the Home Front (London: Little, Brown, 2013; pb. 2014) and Wartime Cumbria, 1939-1945: Aspects of Life and Work (Kendal: Cumberland and Westmorland Antiquarian and Archaeological Society, 2017). They have also recently edited for publication two wartime diaries that were not written for Mass Observation: A Vicar's Wife in Oxford: The Diary of Madge Martin, 1938-1943 (Woodbridge, Suffolk: Oxfordshire Record Society, The Boydell Press, 2018) and The Diary of Leah Aynsley, 1943-1946 (Martlesham, Suffolk: Bedfordshire Historical Record Society, Boydell and Brewer, 2020). The Malcolmsons live in Nelson, British Columbia.

\section{Notes}

Further discussion of issues concerning the context and character of MO's life writings, and their editing and publication, can be found in the four related articles published in this volume.

All individual published MO wartime diaries are listed separately, by diarist's name, in Works Cited.

${ }^{1}$ We are grateful to Adam Matthew for permission use material in the first half of this essay that was presented first in its Mass Observation Online, a digitization of the sources in the Mass Observation Archive with accompanying essays. See www.massobservation.amdigital.co.uk

2 Other and sometimes slightly different statistics are given in Hinton, 139-40, 268.

${ }^{3} \mathrm{~A}$ fine example of such a diary is no. 5331, by Kathleen Hey, a shop assistant in Dewsbury.

${ }^{4}$ Selections from Leonard Adamson's diary have been published, where the emphasis is on his life in Surrey.

${ }^{5}$ There are now four edited books of Nella Last's writing, all published in paperback by Profile Books: Broad and Fleming; and three volumes edited by Patricia and Robert Malcolmson.

${ }^{6}$ For a diary that gives a nice sense of one young woman's multifaceted wartime life, in which the ordinary often mingled with the (by peacetime standards) extraordinary, see Kathleen Tipper.

${ }^{7}$ Happily, the best of these short diaries, by Daidie Penna, has now been published.

${ }^{8}$ The early weeks of Novy's diary are written from Leeds.

${ }^{9}$ A 2007 DVD is available from ITV Studios Home Entertainment.

${ }^{10}$ Although few MO diaries were written by working-class people, many diaries are expressions of a sort of 'history from below', with its attentiveness to common and everyday experiences. This is an approach 
to the past that has always appealed to us, even before our days as research students working with H.J. Dyos at the University of Leicester (Patricia) and E.P. Thompson at the University of Warwick (Robert). 